Cornell Law Library Scholarship@Cornell Law: A Digital Repository

Cornell Law Faculty Publications

Faculty Scholarship

Winter 2006

\title{
Horizontal Agreements: Concept and Proof
}

George A. Hay

Cornell Law School, george.hay@cornell.edu

Follow this and additional works at: http://scholarship.law.cornell.edu/facpub

Part of the Antitrust and Trade Regulation Commons, and the Litigation Commons

\section{Recommended Citation}

Hay, George A., "Horizontal Agreements: Concept and Proof" (2006). Cornell Law Faculty Publications. Paper 1142.

http://scholarship.law.cornell.edu/facpub/1142

This Article is brought to you for free and open access by the Faculty Scholarship at Scholarship@Cornell Law: A Digital Repository. It has been accepted for inclusion in Cornell Law Faculty Publications by an authorized administrator of Scholarship@Cornell Law: A Digital Repository. For more information, please contact jmp8@cornell.edu. 


\title{
Horizontal agreements: \\ Concept and proof
}

\author{
By George A. HaY*
}

\section{INTRODUCTION}

It is well established that, absent some very special circumstances, agreements on price or certain other terms of trade by otherwise competing entities (i.e., "horizontal agreements") are unlawful per se under the Sherman Act. ${ }^{1}$ In practical effect, once the fact of the horizontal agreement has been established, an adverse impact on competition is presumed, and therefore that the plaintiff is spared the burden of proving such an impact. The principal task for plaintiffs in such cases, therefore, is establishing the existence of an agreement. ${ }^{2}$

In the ideal world (from plaintiffs' perspective), there would be "hard" evidence of a "formal" agreement. By "formal" agreement, I

* Edward Cornell Professor of Law \& Professor of Economics, The Cornell Law School.

1 Most of the exceptions involve circumstances where the agreement in question is ancillary to an otherwise legitimate joint venture, such as a league, where it can be demonstrated that the agreement in question is necessary for the joint venture to function effectively. Hence, courts frequently use the term "naked" restraint to describe the situation where the per se rule will apply.

2 In cases involving foreign firms and conduct that occurred in foreign countries, there also may be a dispute about whether U.S. antitrust law, including the per se rule, applies at all. See, e.g., F. Hoffmann-LaRoche v. Empagran, 542 U.S. 155 (2004).

(C) 2006 by Federal Legal Publicattons, Inc. 
mean that the parties actually met or otherwise explicitly communicated agreement on a course of action, and by "hard" evidence, I mean that there is testimony from a live witness present when the communication occurred, a video or audio recording of the communication, or a document created by one of more of the parties that documents the fact of the agreement.

Of course, the world is not always ideal and most of the litigated cases involve situations in which there is no hard evidence of a formal agreement. ${ }^{3}$ In such cases, the plaintiff is forced to ask the court to infer an agreement from circumstantial evidence. However, as we shall see, what makes this task difficult for the plaintiff is that it may involve some complex combination of a detective story (what actually happened?), where economic analysis is often an essential ingredient, and a theoretical legal argument (does what happened constitute an unlawful agreement?). It is the possibility of this complex combination of economic evidence and legal theory that also poses challenges for the court, whether in fashioning instructions for the jury or in ruling on motions (typically by defendants) for summary judgment, directed verdict, judgment notwithstanding the verdict and, most recently, motions to dismiss the complaint for failure to state a claim. ${ }^{4}$ In what follows, I attempt to identify the challenges and to explain when and how economic analysis may be of assistance, but at the same time, identifying areas where the principal concerns are legal rather than economic, i.e., where legal creativity may be required for an effective solution. In that vein, the article will discuss the concept of "facilitating practices" and assess whether the concept may be useful in filling an important gap in the coverage of the Sherman Act.

3 Where there is hard evidence of a formal agreement, the per se rule normally leads to a settlement, since there is little to argue about except for the amount of damages in a private civil suit.

4 Bell Atl. Corp. v. Twombly, 126 S. Ct. 2965 (2006), where a petition for a writ of certiorari was granted. In all likelihood, this case will have been decided by the time this article is published. 


\section{AGREEMENT UNDER THE SHERMAN ACT}

\section{$A$. The legal status of price fixing and related agreements}

Section 1 of the Sherman Act prohibits "[e]very contract, combination in the form of trust or otherwise, or conspiracy, in restraint of trade or commerce among the several States or with foreign nations. ..." At least in the modern era, courts seem not to be concerned about distinguishing among the terms "contract," "combination," and "conspiracy" and most antitrust students are taught simply that the section prohibits agreements in restraint of trade. After allowing for the substitution of "agreement" for the "contract, combination, or conspiracy" triplet, the statute is concise and seems unequivocal. While it turns out that, as the statute has been interpreted over the past hundredplus years, questions have emerged about whether the statute really does prohibit every agreement in restraint of trade, we do not need to spend time discussing the development of the "per se" rule and its application as contrasted with the "rule of reason." For our purposes it is enough to indicate that, unless they occur in the context of a joint venture or in truly extraordinary circumstances, all price fixing agreements among competitors are illegal per se, ${ }^{5}$ as are all boycotts aimed at an actual or potential competitor. ${ }^{6}$ Therefore, in these contexts, as a practical matter the only question is whether in fact an agreement to fix prices or an agreement to engage in a boycott can be established.?

5 Section 1 also covers vertical agreements, including vertical price fixing. While vertical price fixing is also illegal per se, in practice the policy and evidentiary issues are somewhat different, and we will not discuss vertical arrangements in what follows.

6 Often the only way to target a competitor is indirect, e.g., by refusing to deal with an input supplier that also supplies the targeted competitor or refusing to sell to a customer that also buys from the targeted competitor. So in those cases, while there is an immediate victim (the input supplier or the customer), the ultimate target is the competitor.

7 In private treble damage cases, the plaintiff also needs to establish the degree to which the agreement actually affected prices. Hence, some elements of what might otherwise be a "reasonableness" defense come in through the back door in an effort to show that there was no anticompetitive impact. 


\section{B. Explicit agreements}

While the question of whether there is an agreement seems primarily a question of evidence, it is inextricably linked with the more conceptual question of what we mean by an agreement for purposes of enforcing the Sherman Act. As an initial matter, there is no dispute about the proposition that the reference to "contract, combination ... or conspiracy" did not intend to, and does not in fact, limit the coverage of the statute to legally enforceable contracts. Under the common law even the most explicit price fixing agreement, written in ink and signed by all parties, would not have been legally enforceable, yet there is no dispute that such a document would satisfy the definition of agreement under the Sherman Act. Nor does the agreement have to be in writing. The agreement can be oral rather than written (still legally unenforceable), and the antitrust archives are filled with cases in which the parties met to fix prices but there was no written agreement. And, whether the communication is written or oral, it is probably not even necessary that each party say "I agree" or its semantic equivalent; but the slope becomes a bit slippery at this point since, despite the warnings of Adam Smith, ${ }^{8}$ it is possible to imagine situations where a group of competitors are gathered in the same room, ${ }^{9}$ prices are discussed, ${ }^{10}$ and prices go up over some period of time following the gathering, ${ }^{11}$ yet the court would not find that the parties had agreed to fix prices. ${ }^{12}$

8 Adam Smith, An Inquiry into the Nature and Causes of the Wealth of Nations § I.10.82 (Edwin Cannan ed., Methuen \& Co. 1904) (1776) ("People of the same trade seldom meet together, even for merriment and diversion, but the conversation ends in a conspiracy against the public, or in some contrivance to raise prices").

9 For example, doctors from a given specialty at a medical conference.

10 "The insurance companies are pushing prices so low that there is little incentive to remain in this specialty."

11 A significant number of doctors leave the particular specialty in response to what they perceive as unreasonably low prices.

12 This is not to suggest that a competent attorney would not warn his or her clients about the risks associated with attendance at such a meeting or participation in any discussion of prices. 
In any event, for now it is sufficient to assert that any explicit agreement, whether it is reduced to writing or takes the form simply of a face-to-face discussion, or even a direct telephonic or computer exchange, will be enough for Sherman Act purposes. It will be up to the courts to decide whether the precise words that are exchanged in such explicit interactions are enough to constitute an agreement. While some of the conceptual issues I discuss below will be relevant to such a determination, situations in which a group of competitors are in direct communication with one another about future prices are not the ones that give rise to the most serious analytical issues. ${ }^{13}$ The law's basic attitude is that competitors normally have no legitimate purpose for discussing prices with one another (even worse if the discussions occur in secret) and where there is some movement of prices in the wake of such discussions, these "competitors" will face a daunting task of overcoming the presumption that the conversations constituted or resulted in an agreement. ${ }^{14}$

13 Professors Areeda and Hovenkamp offer the following example:

Suppose, for example, that one entrepreneur invites its major rivals to dinner. After dinner, the host announces future price intentions and one or more of the guests do the same. The only objection to finding an agreement to exchange this information is the guests' claim that they were taken by surprise. But we can reject this objection because the guests had an option: although it might have been socially uncomfortable, the guests could have departed as soon as the host began to transform the social occasion into a conspiratorial one.

Phillip E. Areeda \& Herbert Hovenkamp, Antitrust law: An Analysis of ANTItrust Principles and Their Application $\$ 1406 \mathrm{c}$ (2d ed. 2003).

14 A brief discussion about the difference between these two concepts might be productive. Consider the following hypothetical. There is undisputed evidence that the parties met and they all agreed that despite the current market price of $\$ 100$, the industry joint profit-maximizing price would be $\$ 200$. Furthermore, there was discussion of and agreement about the proposition that for any individual firm to charge $\$ 200$ while its competitors maintained the price at $\$ 100$ would be disastrous for the individual firm. However, no firm offered to initiate a price increase and no firm pledged to follow a price increase if one of its competitors initiated it. Yet a few days later, one firm visibly increases its prices and all the rest follow shortly thereafter. There is almost no question that a court would find that this conduct violated the Sherman Act. The court might say either that the discussions 
Courts are also prepared to find illegal agreements even when the communication among the parties is indirect, as opposed to the situation where all the parties are in the room together or are all on the same telephone call. One particularly important example is the socalled "hub and spoke" conspiracy where there is an intermediary that speaks individually to each of the competitors and then relays each competitor's "agreement" to increase prices or engage in some other form of anticompetitive conduct to the other competitors in a series of one-on-one conversations. Thus in Interstate Circuit, ${ }^{15}$ an owner of a chain of first-run theaters (with considerable market power in certain geographic areas) communicated separately with each of eight major film producers and encouraged them to impose onerous (and anticompetitive) terms on the so-called "second-run theaters" that competed to some extent with the owner in question. The Court determined that each film producer would be reluctant to impose such terms on the second-run theaters without some assurance that the other film producers would do the same; the individual communications between the theater owner and each of the individual film producers provided such assurance by making each film producer aware that the theater owner was having similar conversations with each of the producers' rivals. (The Court also indicated that an explicit agreement was not necessary for the plaintiff to have violated the Sherman Act, but we defer a discussion of that part of the opinion for the time being.)

More recently, the same pattern was condemned in the Toys " $R$ " Us case, ${ }^{16}$ where Toys " $R$ " Us (TRU), a major toy retailer, tried to persuade several of the important toy manufacturers to impose unfavorable terms on the discount chains that competed against TRU. When a manufacturer individually indicated concern about being at a com-

constituted an illegal agreement or that the discussions resulted in an illegal (albeit unspoken) agreement or understanding. The latter is probably more precise as a logical matter but the former would probably be regarded as an acceptable legal shortcut. In any event, there would likely be little discussion of the distinction. I will have more to say about such a shortcut in what follows.

15 Interstate Circuit v. United States, 306 U.S. 208 (1939).

16 Toys "R" Us, Inc. v. Federal Trade Comm'n, 221 F.3d 928 (7th Cir. 2000). 
petitive disadvantage if it was the only manufacturer that went along with TRU's demands, TRU allegedly provided the assurance that each of the other manufacturers was being presented with the same demands and eventually assured each manufacturer that each of its competitors would go along so long as everyone else indicated that they would do the same.

\section{Proving explicit agreements}

As a general evidentiary matter, the existence of an explicit agreement can be established either through direct evidence (e.g., a "hot" document, a tape recording of one or more meetings, or a cooperative witness who was present at the meetings), or from circumstantial evidence. While the issue of what circumstantial evidence is adequate to allow a jury to infer that the parties entered into an explicit agreement is not necessarily an easy one, no exotic legal doctrine is required. The issue boils down to an economic detective story in which one side tries to make the case that there is no plausible explanation for the conduct other than some kind of agreement, and the other side tries to explain how the behavior under scrutiny (e.g., parallel price increases) could have come about through normal market forces, or at least from actions that could not fairly be described as constituting an agreement.

Thus, for example, the Court in Interstate Circuit referred to the defendants' "radical departure" from their previous business practices and also to the significant risk that would attach to a single film distributor (i.e., a producer) if only that one distributor were to accede to Interstate's demands. ${ }^{17}$ The clear suggestion was that there was no other plausible explanation for the observed change in the terms imposed on the second-run theaters by the distributors other than some kind of explicit agreement, whether this was achieved by direct communication among the distributors themselves or indirectly, with Interstate acting as the intermediary. Similarly, and hypothetically, if numerous sealed bids for a construction project were opened and found to be identical to the last decimal point, the plaintiff would argue that there is no explanation other than a prior agreement

17 Interstate Circuit, 306 U.S. at 222. 
(achieved, for example, at a hotel-room meeting or via telephone) for the apparent coincidence, and the defendant would try to offer some other plausible, nonconspiratorial, explanation. ${ }^{18}$

In this connection, mere parallel pricing (e.g., all firms increase prices by roughly the same amount in roughly the same time period) is normally not, by itself, enough to allow the inference of an agreement. ${ }^{19}$ The simplest explanation for this is that parallel pricing can occur in competitive markets when all firms experience the same cost or demand factors. ${ }^{20}$ Thus a plaintiff must establish more than mere parallel pricing in order to argue that the observed price increases were not simply the result of the normal competitive process. ${ }^{21}$

\section{The "plus factors"}

While we argued above that the task of establishing through circumstantial evidence whether parallel conduct is the result of an explicit agreement boils down to a relatively straightforward economics-based puzzle (although not necessarily one that is easily solved), courts have attempted to impose some structure on the jury's decisionmaking process by identifying so-called "plus factors," and have instructed the jury that where there is no direct evidence of a formal agreement, an agreement may nevertheless be inferred from parallel

18 For example, a long-standing industry practice of pricing a construction project on a constant dollars per square foot basis.

19 Theatre Enters. v. Paramount Film Distrib. Corp., 346 U.S. 537, 541 (1954) ("Conscious parallelism has not yet read conspiracy out of the Sherman Act").

20 An alternative explanation is that the parallel pricing was the result of oligopolisitic interdependence without any agreement. This explanation is discussed infra.

21 The case where all sealed bids are identical to the last decimal would not be regarded as "mere" parallel pricing. Even in a competitive market, one would normally not expect identical bids in sealed bid situations. Hence, this extraordinary coincidence might support the inference of an agreement unless the defendants could offer a plausible alternative explanation for how it could have come about. As indicated above, see note 4, supra, the Court has agreed to address what, if anything, the plaintiff needs to allege beyond mere parallel conduct, in order to survive a motion to dismiss. 
conduct when one or more "plus factors" are present. Typical is the appellate court's instruction in Blomkest Fertilizer:

An agreement is properly inferred from conscious parallelism only when certain "plus factors" exist. A plus factor refers to "the additional facts or factors required to be proved as a prerequisite to finding that the parallel [price] action amounts to a conspiracy.22

The list of possible "plus factors" has varied from case to casesome are generic and others are quite specific to the circumstances of the case. The plus factors tend to fall in one of several general categories.

The first category has to do with the incentive to collude. The category is structural in the sense that it does not involve looking at the actual conduct at issue but at preexisting conditions that would make it plausible that the potential defendants would have some incentive to try to reach an agreement despite the legal risks. Of course, virtually any industry would find successful collusion to be more profitable than competition, 23 but this factor looks more to the likelihood that collusion would in fact be likely to succeed and not be detected ("evidence that the ... market is one in which secret price fixing might actually have an effect on price and thus be worth attempting"24). Specific factors would include the degree of market concentration, the ease of entry, the homogeneity of the product, transparency of prices, and the presence or absence of large buyers. ${ }^{25}$ It would be surprising, however, for a court to permit the jury to infer agreement from parallel conduct based solely on plus factors in this structural category, no matter how "favorable" they might be.

22 Blomkest Fertilizer, Inc. v. Potash Corp. of Sask., 203 F.3d 1028, 1032-33 (8th Cir. 2000) (citations omitted).

23 The one exception would be an industry that faces a perfectly elastic demand curve; therefore, even if operating cooperatively, it would have no ability profitably to increase price above the competitive level.

24 In re High Fructose Corn Syrup Antitrust Litig., 295 F.3d 651, 656 (7th Cir. 2002).

25 These factors are discussed in more detail in section IV B, infra. See also, George A. Hay, Oligopoly, Shared Monopoly, and Antirust Law, 67 CoRnelL L. REv. 439 (1982). 
A second category, which is perhaps best thought of as a blend of structural and behavioral factors, represents "opportunities to collude," and refers primarily to the existence of frequent interfirm communications. ${ }^{26}$ These interfirm communications can be innocuous in and of themselves (e.g., situations where executives of the various defendants were in attendance at the same trade association meeting) and therefore suggest merely the possibility of nefarious "off-therecord" communications, or the communications can be presented as inherently suspicious behavior (e.g., frequent telephone calls between relevant employees of various industry participants) in the absence of some alternative explanation for the communications. Again, it would be rare for a court to permit a jury to infer an unlawful agreement based merely on parallel conduct combined with frequent interfirm communications. There must normally be some additional effort to focus on the conduct itself beyond merely characterizing the conduct as parallel or even "consciously parallel." 27

A third category could be labeled "coincidence" factors and would apply in situations where the nature of the market is such that firms cannot easily observe (and therefore follow, if they so desire) other firms' actions. Hence, as discussed above, when a sealed process yields multiple identical bids, the sealed nature of the process would be a plus factor tending to suggest that such a coincidence would not have been plausible absent a prior agreement. ${ }^{28}$ In Interstate Circuit, the Court regarded it as significant that the contract terms from each of the eight film distributors were essentially identical by the time they were finalized despite the fact that they were radically different from the terms in the previous contracts and despite the fact that the terms evolved over the course of what were supposedly individualized negotiations between Interstate and each of the

26 See, e.g., Apex Oil v. DiMauro, 822 F.2d 246 (7th Cir. 2002).

27 Conscious parallelism means simply that the various firms were aware of other firms' conduct when they made their own decisions. But this can occur for virtually any consumer product where the same mechanism that firms use to inform consumers of their prices inevitably also informs other firms.

28 See, e.g., Federal Trade Comm'n v. Cement Institute, 333 U.S. 683 (1948); C-O-Two Fire Equip. Co. v. United States, 197 F. 2 d 489 (9th Cir. 1952). 
eight distributors. These circumstances made it implausible that the terms of each of the eight contracts could have wound up being identical by coincidence and made it likely that the real explanation was an agreement among the eight orchestrated by Interstate. ${ }^{29}$

The last category of plus factors is a catchall category that focuses on the actual conduct at issue and, in the most general sense, is used to persuade the jury that the conduct can best be explained as stemming from agreement as opposed to independent decisionmaking on the part of each individual firm. While there is some overlap with the "coincidence" category, the factors in this last category apply even in situations where firms can observe other firms' actions and are used to suggest that this is not a sufficient explanation for the parallel conduct. ${ }^{30}$

The most frequently referenced plus factor in this category is sometimes described as a party taking action against its own self-interest, but this loose phrasing is misleading because economists generally believe that a firm never acts contrary to its own self-interest. From the plaintiff's perspective, the plus factor would be that the conduct is rational (i.e., consistent with a firm's own self-interest) only in the context of a prior agreement that all other competitors behave similarly. The defendant's best response is that its own conduct is rational (i.e., consistent with its own self-interest) regardless of what the other competitors do (and therefore no prior agreement is necessary).

A good illustration of this defense argument occurred in Theatre Enterprises, ${ }^{31}$ where the defendants persuaded the Court that refusing

29 Interstate Circuit v. United States, 306 U.S. 208, 221 (1939).

30 Of course, in the case of parallel conduct, it is virtually impossible for a given defendant to "prove the negative," i.e., that there was no conspiracy, since it will almost always be possible that the parallel conduct was the result of an agreement, but the core of the each defendant's argument is that the conduct can readily be explained as arising from independent decisionmaking and therefore there is no basis for believing that a conspiracy was likely.

31 Theatre Enters. v. Paramount Film Distrib. Corp., 346 U.S. 537, 540 (1954). The Crest was in suburban Baltimore and, under the exclusive dealing arrangements that were common in the industry, each movie distributor had to decide whether to open a new film in one of the traditional large, 
to deal with the Crest made sense for each defendant regardless of what the others did, and hence there would be no motive to enter into a conspiracy. Each defendant may have expected its rivals also to refuse to deal with the Crest but that is neither surprising nor relevant so long as each defendant can say that it would still have refused to deal with the Crest even if it knew that one or more of its rivals would behave differently. Similarly, when a firm's raw material costs go up in a highly competitive market, it will want to increase price and it will expect that rivals will do the same. However, the firm's decision is not contingent on what its rivals do, as it is better to lose some sales than to be selling below cost.

\section{E. The "oligopoly defense"}

While the ideal defense to a claim of conspiracy based on parallel conduct is that each firm's behavior is rational regardless of what its competitors do (and therefore there is no need to posit a prior agreement to explain the parallel conduct), this defense will not always be available, particularly in markets that are characterized by oligopoly. The following hypothetical provides a useful reference point:

Consider two gas stations across the street from one another that are the only two stations for miles around with (for whatever reason) no likeli-

downtown theaters, or to give it to the Crest. Given the demographics of the time, the Court in effect concluded that a rational jury could have decided that each distributor might have preferred to deal with the downtown theaters rather than with the Crest. The court, in rejecting plaintiff's claim that the trial court should have directed a verdict in its favor, used the oft-quoted sentence: "Circumstantial evidence of consciously parallel behavior may have made heavy inroads into the traditional judicial attitude toward conspiracy; but "conscious parallelism" has not yet read conspiracy out of the Sherman Act." Id. at 541. Whatever the Court meant to signal by this passage, the use of the phrase "conscious parallelism" in this context was probably ill advised. To economists, the phrase has usually referred to a situation of oligopolistic interdependence, where each party's best choice is very much dependent on what its rivals do. But, as suggested above, there may not have been any interdependence in Theatre Enterprises. Each distributor made a decision that was independently rational. Whatever the law's attitude toward oligopolistic interdependence, see section IV infra, no sensible commentator would suggest that independently rational conduct should be the basis for an inference of unlawful conspiracy. 
hood of entry in the foreseeable future. Assume that the profit-maximizing cartel price is $\$ 2$, and that this is clear to both sellers, but there is no brand loyalty; i.e., consumers will buy from whichever is cheaper and each has the capacity to service most or all of the customers. (If both charge the same price, each will get half of the total sales.) Hence the two stations collectively have a degree of market power but there is little or no individual market power. Finally, assume further that, to this point, each firm has been selling at $\$ 1$.

In this scenario, each firm would wish that the market price were $\$ 2$ but would also realize that if one firm were to raise the price to $\$ 2$ and the other were to maintain the price at $\$ 1$, the firm initiating the price increase would lose all its business to the firm with the lower price. If that happened, the high-price firm would be worse off than the status quo and the low-price firm would be better off. Hence, at first blush, it appears that neither firm will want to initiate the price increase without prior agreement that its rival will follow. Hence, it would appear that, absent agreement, prices will gravitate toward the competitive level.

However, that need not be the case. Assume that by law or industry custom, prices are posted prominently on signs in front of each station. Each firm realizes that if it increases price to $\$ 2$ it can easily see whether the other has followed and can rescind the price increase promptly if it observes that the other has not. Consumers cannot easily store gasoline, so only a limited volume of sales will shift in the interim before the price collapses back to $\$ 1$. Thus, there is very little risk in initiating a price increase. From the second firm's perspective, the short-run advantage of not following a rival's price increase is limited and the long-run consequence may be to preserve the lower price. Hence, it can be in the second firm's interest to follow a rival's price increase, and the rival knows this. ${ }^{32}$ The result is that the market price can move to (and remain at) $\$ 2$ without any direct or indirect communication between the parties, unless one counts the posting of the price as "communication." 33

32 While the intuition supporting the hypothetical seems straightforward, the formal modeling of the hypothetical can be more complex. In a simple one-period game, the optimal strategy for the second firm is not to follow, and simply adding a fixed number of additional periods doesn't necessarily change the optimal strategy. See, e.g., Gregory J. Werden, Economic Evidence on the Existence of Collusion: Reconciling Antitrust Law with Oligopoly Theory, 71 ANTTRUSt L.J. 719, 728-34 (2004).

33 Therefore we might have used the phrase "prohibited communication" since, for reasons discussed below, it is implausible that a court would prohibit signs intended to notify consumers about an outlet's prices simply because that sign also provided information to rival outlets. 
Note that, in this hypothetical, each station may be just as confident of how its competitor will act as it would have been had they met in a hotel room the previous night and "agreed" to a parallel increase. ${ }^{34}$ And, by assumption, $\$ 2$ is not a "competitive" price; consumers are hurt just as badly as if the sellers had conspired explicitly. ${ }^{35}$ Moreover, it is not quite right in this hypothetical to say that each party's action is independently rational, at least in the sense used above. Each seller's profits depend critically on what its rival does, and neither would increase price if it knew that its rival would not. The parties' fates are very much interdependent, much like the interdependence that would prevail in a typical cartel.

However, in contrast to the typical cartel, to the extent that each firm is confident that its rival will follow a price increase, that confidence flows not from any prior communication or (explicit) agreement, but from the very nature of their market: only a few firms exist, barriers to entry are high, prices are very visible, and there is no chance for one rival, by maintaining a low price, permanently to lock up any significant chunk of business in the period before the other rescinds its price increase. ${ }^{36}$ Each party's conduct is rational regardless of any prior communication or explicit assurance from the other. Therefore, there is no basis for an inference that any explicit communication or agreement has occurred. ${ }^{37}$

34 Indeed, in a cartel with not two, but many, participants, the degree of confidence that rivals will cooperate may be quite limited.

35 In a more realistic example, it might take several iterations (i.e., a price increase initiated, not followed, retracted, reinstituted, etc.) before a supracompetitive equilibrium is reached, and that equilibrium might not replicate exactly the cartel joint profit-maximizing price but instead be somewhere between the competitive price and the cartel joint profit-maximizing price.

36 This is not to suggest that many classic cartels do not also display some of the features (e.g., small number of firms, price transparency, etc.) that would give rise to a degree of interdependence. Indeed, an interesting aspect of the damage phase of private actions against cartels is the claim by the defendants that, but for the conspiracy, prices would not be competitive but rather much higher (perhaps approaching or approximating the cartel price) due to oligopolistic interdependence.

${ }^{37}$ In a sense, the degree of interdependence is so high that the parties can act independently, i.e., without any prior communication or express commitment. 


\section{TACIT OR IMPLICIT AGREEMENTS}

What recourse does a plaintiff have when a defendant credibly establishes the oligopoly defense; i.e., the defendant shows that while the competitors' actions are very much interdependent, there is no reason to posit a prior explicit agreement to explain the parallel conduct? While each firm's conduct is rational only if its competitors act similarly, the firm has every reason to be confident that they will do so without the need for any explicit communication or prior commitment.

The threshold question posed is whether the Sherman Act actually requires an explicit agreement or whether liability can attach to something less explicit, which might be referred to as a "tacit" or "implicit" agreement. Some courts have indicated that an explicit agreement, whether established through direct evidence or through circumstantial evidence, is not necessary for firms to be liable under the Sherman Act. ${ }^{38}$ In Interstate Circuit, the Court opined that, while the circumstantial evidence of an actual agreement was persuasive, there was an alternative path the government might have taken:

It is elementary that an unlawful conspiracy may be and often is formed without simultaneous action or agreement on the part of the conspirators. Acceptance by competitors, without previous agreement, of an invitation to participate in a plan, the necessary consequence of which, if carried out, is restraint of interstate commerce, is sufficient to establish an unlawful conspiracy under the Sherman Act. ${ }^{39}$

The idea, then, is that a group of firms may be able to achieve cartellike results without any explicit communication, but they may be

38 It should be noted, however, that when some courts use the term "tacit agreement" they mean simply to refer to any agreement, including an explicit agreement that is established through circumstantial evidence rather than through direct evidence. See, e.g., William E. Kovacic, The Identification and Proof of Horizontal Agreements under the Antitrust Laws, 38 ANTITRUST Bull. 5,20 (1993). This use of the term "tacit agreement" may be careless from a grammatical perspective and may confuse the issue of what kinds of circumstantial evidence can be used to establish the existence of an agreement, but does not raise any novel theoretical issues. In what follows, however, the focus is on whether there is a substantive, not merely evidentiary, basis for the concept of tacit collusion.

39 Interstate Circuit v. United States, 306 U.S. 208, 227 (1939) (citations omitted). 
found to have engaged in or achieved a "tacit" agreement that is prohibited by the Sherman Act. Of course, just as pure parallel conduct cannot be used as the sole evidentiary basis for the finding of an explicit agreement, neither can it support a finding of a tacit agreement since parallel conduct can result from competitive conduct when firms are confronting similar external forces such as increases in their raw material costs. When that happens, each firm's decision is made independent of what the others might do.

However, in our hypothetical, the firm initiating the price increase is issuing an invitation which, if followed, results in a price significantly above the competitive level (i.e., a restraint of commerce). When the rival matches the increase, it has accepted the invitation. Therefore, the language of Interstate Circuit might suggest that we have an unlawful conspiracy. We know that consumers are hurt just as much as if there were an explicit cartel, and the parties are acting just as they would have had they entered into an explicit agreement. It would appear, then, that this is the perfect opportunity to use the concept of a tacit or implicit agreement-a "meeting of the minds." What's the problem?

Numerous commentators have discussed the theoretical and practical problems associated with a finding of an unlawful conspiracy on such facts, notwithstanding the "invitation" of the Interstate Circuit court. ${ }^{40}$ The consensus seems to be that, standing alone, the pattern of conduct described in the hypothetical, which I have elsewhere termed "pure oligopoly," 41 cannot-and should not-constitute a Sherman Act violation. The core of the problem is that there is no conduct that can fairly be described as "culpable." It would make no sense, for example, to counsel a firm that it is free to raise prices but only so long as those prices are not matched by a competitor, or that the firm cannot match another competitor's higher price if it believes that the higher price will increase its own profits. Alternatively,

40 See, e.g., Donald F. Turner, The Definition of Agreement Under the Sherman Act, 75 Harv. L. Rev. 655, 663-66 (1962); see also John E. Lopatka \& William H. Page, Posner's Program for the Antitrust Division: A Twenty-Five Year Retrospective, 48 SMU L. REV. 1713, 1719 (1995).

41 Hay, supra note 25. 
imagine counseling a firm that it can initiate a price increase without fear that, if it is matched by competitors, they will all be guilty of a Sherman Act violation, but only if that price increase is "cost-justified," i.e., it cannot fairly be labeled a "supra-competitive price." This would make the difference between lawful and unlawful conduct (with the associated criminal penalties and exposure to treble damages) turn on the size of the price increase or, rather, the court's ex post evaluation of whether the price increase was reasonable, and this is a task which Sherman Act courts have traditionally been reluctant to accept. ${ }^{42}$

Several courts have reached the same conclusion and have voiced similar concerns. For example:

Courts have noted that the Sherman Act prohibits agreements, and they have almost uniformly held, at least in the pricing area, that such individual pricing decisions (even when each firm rests its own decision upon its belief that competitors will do the same) do not constitute an unlawful agreement under Section 1 of the Sherman Act. ${ }^{43}$

Another example, from the Ninth Circuit:

To permit an antitrust violation to be based on the ... price pattern in this case, without more, would require a company making wholly independent pricing decisions to consider that the possible responses of its competitors might render it liable for treble damages. Similarly, following another company's price increase might very well provide the evidence that a disgruntled customer would need to get to a jury in a treble damage antitrust suit. It thus appears that permitting an inference of conspir-

42 In Addyston, Judge Taft suggested that any court that presumed to accept the responsibility for deciding whether a given price was reasonable would "set sail on a sea of doubt." United States v. Addyston Pipe \& Steel Co., 85 F. 271, 284 (6th Cir. 1898). The one notable dissent from this consensus is the one Judge Posner referred to earlier. While Posner seems to believe that, in fact, courts will not recognize the concept of tacit agreement at all, he advocates using the label and condemning conduct even in circumstances that others would describe as pure oligopolisitic interdependence. Put simply, Posner believes that firms cannot achieve a supra-competitive price without engaging in behavior that he would regard as culpable. RICHARD A. POSNER, ANTITRUST LAW 51-60, 93-100 (2d ed. 2001).

43 Clamp-All Corp. v. Cast Iron Soil Pipe Inst., 851 F.2d 478, 484 (1st Cir. 1988) (citing Apex Oil Co. v. DiMauro, 822 F.2d 246, 253-54 (2d Cir. 1987); North Carolina v. Chas. Pfizer \& Co., 384 F. Supp. 265 (E.D.N.C. 1974)). 
acy from the parallel pricing evidence alone would result in an anticompetitive dislocation by distorting independent pricing decisions. ${ }^{44}$

Therefore, if there is to be substance to the concept of a tacit agreement, it must be defined in such a way that it does not extend to supra-competitive pricing arising purely from oligopolistic interdependence. If that can be done, there could then be four different ways to characterize parallel conduct:

a) the conduct, albeit parallel, is independent and hence competitive; consumers have not been injured and there is no reason to look further for an explanation;

b) the parallel conduct is interdependent and hence not truly competitive; the conduct is the result of an explicit agreement which can be established through either direct or circumstantial evidence;

c) the parallel conduct is interdependent, and hence not truly competitive; the conduct is the consequence solely of oligopolistic interdependence; there is no reason to infer any kind of agreement;

d) the parallel conduct is interdependent and hence not truly competitive; while there is no reason to believe that there was an actual agreement, the conduct is not attributable solely to oligopolistic interdependence; rather it was the result of a tacit agreement, which can be established on the basis of circumstantial evidence. ${ }^{45}$

44 In re Coordinated Pretrial Proceedings in Petroleum Prods. Antitrust Litig., 906 F.2d 432, 444 (9th Cir. 1990). There may be a semantic confusion embedded in the court's reference to the pricing as "independent." When prices are at supra-competitive levels, the various firms' decisions are very much interdependent. Nevertheless, the decision may be rational without any prior communication among the firms given the structure of the market.

45 To be sure, some courts have expressed doubts about whether a tacit agreement, however defined, violates the Sherman Act. As Judge Posner noted in High Fructose Corn Syrup:

Section 1 of the Sherman Act forbids contracts, combinations, and conspiracies in restraint of trade. This statutory language is broad enough . . . to encompass a purely tacit agreement to fix prices, that is, an agreement made without any actual communication among the parties to the agreement. ... Nevertheless it is generally believed ... that an express, manifested agreement, and thus an agreement involving actual, verbalized communication must be proved to be actionable under the Sherman Act.

In re High Fructose Corn Syrup Litig., 295 F.3d 651, 654 (7th Cir. 2002). 
The principal problem, as we have discussed, is in distinguishing between (c) and (d). ${ }^{46}$ As I have said elsewhere, ${ }^{47}$ telling a jury that it can infer tacit collusion from circumstantial evidence (including plus factors) is not helpful unless the jury is given more information about what it is actually looking for. ${ }^{48}$ Without a working definition of a tacit agreement and an understanding of how it differs from pure oligopolistic interdependence, there is no basis on which a jury can decide whether or not a tacit agreement has occurred or why the hypothesis of a tacit agreement is more plausible than the hypothesis of pure oligopolistic interdependence. Unless the presence of certain plus factors is meant actually to define a tacit agreement (rather than permit the jury to infer such an agreement), the courts need to explain how, despite the presence of several of these plus factors and interdependent conduct, a jury might rationally conclude that there was no tacit agreement, and that the parallel conduct was the natural result of the oligopoly structure. ${ }^{49}$

46 A useful way to frame the problem is to imagine a situation in which the jury is asking the trial judge for guidance. The jury has reported that they do not believe that the prices are really competitive; they seem to be well above any reasonable measure of costs and the parties seem to have been very profitable over the relevant period. But the jury has also reported that they have not seen any direct evidence of a formal agreement and the circumstantial evidence has not persuaded them that the parties ever met or communicated in any way. The judge explains to the jury that it is not necessary that the jury find that the parties explicitly agreed so long as they find there was a tacit or implicit agreement, but then must explain to the jury what actually is meant by the concept and how it differs from conscious parallelism (i.e., pure oligopolisitic interdependence).

47 George A. Hay, The Meaning of "Agreement" under the Sherman Act: Thoughts from the "Facilitating Practices" Experience, 16 REv. INDUs. ORG. 113, 128 (2000).

48 When juries are engaged in their more traditional role of inferring an explicit agreement from circumstantial evidence, they know what they are looking for and thus merely need to decide whether the circumstantial evidence points unequivocally in that direction (as opposed to competitive conduct or conscious parallelism).

49 Of course, if the jury concludes that the conduct, although parallel, is still independently rational, i.e., competitive, then there is no problem in rejecting the section 1 claim, notwithstanding the presence of plus factors. But the text refers to situations where it is clear that the conduct was interdependent, i.e., not really competitive, and the only issue is whether it is attributable to a tacit agreement or solely to oligopolistic interdependence. 


\section{FACILITATING PRACTICES AND OLIGOPOLISTIC INTERDEPENDENCE}

\section{A. Introduction}

At the most general level, facilitating practices are actions taken by the parties to make coordination easier or more effective. Thus one could characterize the archetypical hotel room meeting as a facilitating practice because it makes reaching an agreement on price easier. As the term has usually been applied, however, it has the narrower meaning of specific actions taken by firms to make coordination easier or more effective without the need for an explicit agreement. The idea is to fill in the gap between explicit agreement and pure oligopolistic interdependence without simply invoking an epithet such as "tacit agreement," and its attendant "plus factors," which may have little or no operational content..$^{50}$ To make use of the facilitating practices concept, I examine more closely those situations of interdependent conduct where there is no evidence of an explicit agreement and the defendant's claim is that the oligopoly structure of the market made explicit agreement unnecessary. In the course of that examination I analyze whether it is structure alone which explains the poor performance of the market or, rather, whether the parties have taken certain specific actions (short of formal agreement) without which the market would likely have functioned more competitively.

\section{B. Structural factors affecting successful coordination}

To better understand the possible role of facilitating practices and to provide background for the discussion of the cases that have invoked the concept, it is useful to review briefly what is known about the relation between market structure and market performance..$^{51}$ At one extreme, even a formal, explicit agreement is unlikely to be effective if the market structure is very unfavorable to coordination. To take the simplest example, if there are one hundred

50 This does not necessarily imply abandonment of the term "tacit agreement" but rather can be seen as an effort to make it operationally meaningful.

51 For an excellent summary of the relationship between market structure and market performance, and the role of game theory in effecting that link, see Werden, supra note 32. 
roughly equal-sized firms in the market, even a formal cartel is unlikely to be very effective for very long, absent the involvement of the government as an organizer and enforcer..$^{52}$ Thus, while there is no bright line, a certain amount of concentration is a necessary condition for effective coordination. ${ }^{53}$

More generally, for a cartel to be effective, two things are necessary. First, the firms must be able to coordinate their actions, assuming that they want to do so. If, for example, the product is not fungible, so that each firm's offering is at least somewhat different from the offerings of its rivals, and there are numerous firms, it will be more difficult to agree on a particular price or array of prices, even if the firms spend hours or days in direct contact with one another. The problem becomes even more complex if important characteristics of the product change over time either through marketing initiatives or through actual technical improvement. Moreover, different firms will have different ideas about what constitutes the optimal cartel price either due to divergent estimates of consumer demand or to different time horizons and therefore different discount rates applied to future profits. ${ }^{54}$ These differences must be resolved in order for an agreement to be effective. Face-to-face contact helps to resolve the differences but does not guarantee that they will be successfully resolved.

52 For example, in the days before deregulation, the government, through the Interstate Commerce Commission, effectively acted as a cartel ringmaster for the trucking industry, which was not a highly concentrated industry. Motor Carrier Act of 1935, 49 U.S.C.A. \$ 206(a) (repealed 1980) (requiring that all interstate carriers be "certified" by the ICC, thus allowing the Commission to implement uniform tariff rates, which effectively prevented competition between large volume and small volume carriers).

53 See, e.g., George A. Hay \& Daniel Kelley, An Empirical Survey of Price Fixing Conspiracies, 17 J.L. \& ECON. 13 (1974).

54 Thus, for example, as one reads about the discussions that take place in the world's most public cartel, OPEC, one sees disputes about the possible long-run consequences of setting the benchmark price for crude too high, possibly leading to consumer substitution, technological change, or new entry, with some OPEC members willing to take a much longer-run view than other members, possibly reflecting a more advantageous short-run wealth position, while other, less wealthy, countries may be more interested in maximizing near-term profits. 
Second, assuming firms are able to cooperate, the firms must want to cooperate; i.e., there must be incentives to cooperate rather than to compete. Thus, for example, if prices are not transparent, so that firms cannot easily monitor the prices being charged by their rivals, there will be incentives to "cheat" even where the parties have reached an explicit agreement, since the cheater may be able substantially to increase its market share at prices only slightly less than the agreedupon cartel price. ${ }^{55}$ This problem will be exacerbated if sales are "lumpy" so that a lot of incremental business can be captured in the window before rivals learn that one of them has been shading prices below the "agreed upon" levels. If prices are not transparent and sales are lumpy, even a formal cartel is unlikely to be successful absent some extraordinary enforcement mechanism, because merely the risk that the cartel agreement may collapse may not be enough to discourage cheating, given the potential short term gains from cheating. ${ }^{56}$

So, at one market structure extreme, coordination may be so difficult and cheating so attractive that even a formal cartel may not be effective..$^{57}$ At the other market structure extreme, where there are only a small number of competitors, the product is highly fungible, prices are transparent, and sales are not particularly "lumpy," the parties might be both able and willing to coordinate their activities without any formal agreement or any other specific actions that might be regarded as out of the ordinary. Thus, in the gas station example used earlier, one firm (without prior consultation with its competitor)

55 Indeed, the very fact that the cartel price is above the competitive price creates the incentive to cheat since, once price is elevated substantially above incremental cost, there are substantial profits to be earned if one firm can increase its own sales volume by shading prices only slightly.

56 If the gains from cheating are very temporary (because cheating can be detected quickly) and small (because the cheater cannot garner substantial sales volume during the window when its prices are lower than its rivals), then simply the risk that cheating will undermine the cartel may be enough to motivate firms to cooperate.

57 Hence, there may be some industries in which effective collusion would be impossible to achieve even in the absence of legal prohibition. The fact that the antitrust laws make formal collusion unlawful makes it that much more difficult for a cartel to function effectively, since cartel activities must be kept secret. 
makes an educated guess as to the profit-maximizing "cartel" price and posts that price, and the other, noting the higher price, sees it as in its own self-interest to match that price rather than to try to garner a short-run advantage by offering a lower price (which would quickly be matched by the original price setter). The result is a supra-competitive price and supra-competitive profits but neither firm has done anything that is likely to be regarded as actionable under section $1 .{ }^{58}$

\section{Actions to overcome the structural factors affecting successful coordination}

Between the two extremes outlined above there is a large middle range of industry structures in which effective coordination is feasible, but only if parties take certain steps to resolve the cartel problems described above, i.e., to achieve some kind of understanding about the ideal industry price (or array of prices) and to discourage cheating by creating conditions that make cheating unlikely to be effective. In some cases, these steps may include entering into an explicit agreement, with face-to-face meetings or other forms of formal communication. In other cases, however, formal communication may not be necessary as long as firms take certain specific steps (short of formal communication) to facilitate a tacit agreement.

For example, suppose that in the normal course of business prices are transparent, but only with a considerable lag. Each firm's prices eventually become known (accurately) to its competitors, but only after several weeks. Thus a firm that wants to initiate a price increase knows that it will be at least several weeks before its rivals see the price increase, who may then respond if they want to. This alone means that the firm that initiates the price increase will stand to lose sales until its rivals are able to respond. But, in addition, the rivals know that, if they fail to match the increase, it will be another several weeks before the first firm knows whether the others have followed. This may create an

58 This is true even if one might describe the parties as having a "meeting of the minds" as to the wisdom of maintaining price at the elevated label and as to the foolishness of trying to gain a short-run advantage by cutting price below that of one's rival. Hence, while one might use the words "tacit agreement" to describe what is going on, applying the label does not advance the legal analysis. 
incentive not to follow since in the multiweek window, enough business can be captured to make it worthwhile. In any event, the risk for the first firm becomes simply too much to bear and it makes the decision that it will not be the one to initiate a price increase unless subsequent cost increases make current prices not viable.

But suppose now the first firm decides to make its prices public on the day that the higher prices are implemented. Then the rivals immediately know what price to match if they want to. This then cuts in half the window of exposure for the first firm..$^{59}$ The window is reduced altogether if the rivals decide to announce their own price decisions right away. Or, to take it even further, suppose the first firm announces today that it intends to increase price to a specific amount effective two weeks hence (with the implicit threat to rescind the price increase if rivals do not promptly announce their own intentions to match the price increase). This has the added advantage that, if one or more rivals thinks that the first firm's announced price increase was too much for industry profit maximization, any of them can "suggest" $^{\prime \prime}$ a lower price in the window before any price increases have taken effect, without causing the first firm to lose any sales as a result of its rivals' failure to match its price exactly.

The idea, then, is that successful coordination would not be possible (or would be much less likely) without these extra steps-the facilitating practices. There has been neither explicit agreement on price nor even explicit agreement to make the price announcements public. But the clear purpose of the public announcements was to facilitate coordination and (by assumption) there was no other business reason for making the public announcement about (future) prices. The announcements are the arguably "culpable" acts that have facilitated successful coordination on price. The question is whether these culpable acts can be reconciled with the Sherman Act's requirement of an "agreement," and if so, how. ${ }^{60}$

59 The rival firms know right away that the first firm has increased price and they know the new price; but the first firm must still wait to learn whether the rivals have followed.

60 Another tack would be to assert that there was a tacit agreement among the firms to make price announcements public and that this agreement was unreasonable and therefore unlawful. This simply takes us back to 


\section{Fitting the facilitating practices concept into the Sherman Act}

To see how the concept of facilitating practices can fit into the Sherman Act framework, consider the four different possible explanations for parallel conduct discussed above:

a) the conduct, albeit parallel, is independent and hence competitive; consumers have not been injured and there is no reason to look further for an explanation;

b) the parallel conduct is interdependent and hence not truly competitive; the conduct is the result of an explicit agreement which can be established through either direct or circumstantial evidence;

c) the parallel conduct is interdependent, and hence not truly competitive; the conduct is the consequence solely of oligopolistic interdependence; there is no reason to infer any kind of agreement;

d) the parallel conduct is interdependent and hence not truly competitive; while there is no reason to believe that there was an actual agreement, the conduct is not attributable solely to oligopolistic interdependence; rather it was the result of a tacit agreement, which can be established on the basis of circumstantial evidence.

Recall the difficulty of trying to distinguish between (c) oligopolisitic interdependence and (d) tacit agreement. By invoking the concept of facilitating practices, we convert (d) into the following:

the issue of what constitutes a tacit agreement when there has been no discussion among the firms about making such price announcements. If we are going to use the phrase "tacit agreement," it is simpler just to say there was a tacit agreement on price and deal with the conceptual and evidentiary problems directly.

Finally, there is one other potential approach that does not involve section 1 at all. A plaintiff could seek to challenge the actions of one or more firms as an attempt to monopolize, unlawful under section 2 of the Sherman Act. The argument would be that the implementation of certain facilitating practices by one or more firms would have or did have the consequence of eliminating competition and permitting the industry to engage in monopoly pricing. Possible support for this approach would be the Justice Department's case against American Airlines for inviting its competitor, Braniff Airlines, to cooperate on pricing. Since Braniff rejected American's overtures, there was no conspiracy, and section 1 contains no direct prohibition of an attempt to conspire. Hence, the government proceeded, successfully, under section 2. See United States v. American Airlines, 743 F.2d 1114 (5th Cir. 1984). 
d) the parallel conduct is interdependent and hence not truly competitive; while there is no reason to believe that there was an actual agreement, the conduct is not the consequence solely of oligopolistic interdependence; rather it depended critically on certain other actions taken by the parties to facilitate coordination; while this conduct would not normally by itself be unlawful, its use in this context is culpable, and it is reasonable to label the conduct as leading to, or as constituting, an unlawful tacit agreement.

\section{E. Facilitating practices and the courts: an illustrative survey}

There have been relatively few cases focusing specifically on facilitating practices as the essence of the violation (and using the facilitating practices terminology) and several of the most important efforts to apply the concept were settled rather than litigated. The following are notable examples of the use of the facilitating practices approach. ${ }^{61}$

1. GE-WESTINGHOUSE The first such case to gain widespread attention was the Department of Justice's action against General Electric (GE) and Westinghouse, which resulted in the modification of a preexisting consent decree in 1977. ${ }^{62}$

In 1960, GE, Westinghouse, Allis-Chalmers, and four individuals were indicted for fixing the prices of large turbine generators. The criminal case ultimately resulted in the entry of guilty pleas by the corporate defendants and nolo contendere pleas by the four individual

61 I do not discuss cases in which state-imposed regulations are alleged to facilitate tacit collusion among private actors (e.g., state "post and hold" statutes, which require liquor distributors to announce price lists and to adhere to the posted prices). For an extensive discussion, see John E. Lopatka \& William H. Page, State Action and the Meaning of Agreement Under the Sherman Act: An Approach to Hybrid Restraints, 20 YALE J. ON REG. 269, 310-18 (2003).

${ }^{62}$ This summary is taken in large part from the Justice Department's 1977 Competitive Impact Statement in the GE-Westinghouse matter, United States v. GE Co. (1977-1) Trade Cas. (CCH) 712, and is substantially identical to the section on GE-Westinghouse that appeared in Hay, supra note 25. Because the matter was not litigated, any "facts" provided in this summary are essentially assertions of the Justice Department, and it must be assumed that some of the conclusions drawn would have been resisted by the parties. 
defendants, which in turn resulted in fines and, in the case of one individual, a jail sentence. The companion civil case led to a consent decree against the corporate defendants generally prohibiting price fixing and the kinds of direct communications that had been at the heart of the original conspiracy.

Vigorous price competition apparently prevailed in the industry from 1960 into 1963. By 1962, Allis-Chalmers had withdrawn from the market but there was still substantial overcapacity and prices continued to decline. Relatively few sales were made in any year, and the pressure to obtain any given order was substantial. Moreover, the product was not homogeneous and, although price books were used, there was little adherence to published prices and considerable discounting occurred on particular projects.

However, in May 1963, GE announced a new pricing policy, which featured GE's intention to adhere to published prices on all future transactions. The revised policy had a number of elements designed to facilitate its success. ${ }^{63} \mathrm{~A}$ key element was a revised price book which contained simplified formulas and procedures for determining the book price of any given turbine generator and a published multiplier to be applied to book prices at any given time so as to determine the actual bid prices for any given project at that time. (For example, the published multiplier for May 1963 was .75, which meant that the price that would actually be quoted to any customer would be .75 times the book price.) The use of the multiplier permitted GE to make swift changes in price without the complexity inherent in printing an entirely new price book. The combination of the announced no-discount policy, the revised, simplified price book and the use of the published multiplier made it much easier for Westinghouse to know what GE would bid on any given turbine generator project and therefore easier to match GE's price, if it wanted to.

Another key feature of the new policy was the use of "price protection" clauses in all future contracts with customers. Under these

63 In what follows, I identify only the major elements of the policy. Readers who are not already familiar with the GE-Westinghouse matter can consult the Competitive Impact Statement or other sources such as Hay, supra note 25 . 
clauses, if GE lowered its price for a particular customer, then every other customer who had paid list price during the previous six months would be entitled retroactively to the same discount. The consequence of the price protection clause was that selective price cuts in individual transactions could not be employed by GE without imposing substantial penalties on itself in the form of retroactive discounts to other customers. The result was to give assurance to Westinghouse that GE would be adhering to its stated policy of not giving discounts. In other words, the price protection clause removed any incentive to "cheat."

The net effect of all aspects of the new GE policy was to make it possible for Westinghouse to match exactly GE's prices if it wanted to and to give some assurance to Westinghouse that, in matching GE's published prices, it would not be incurring any risk of being secretly undercut by selective discounts. This did not guarantee, of course, that Westinghouse would in fact match GE's prices, but there would be a strong incentive to do so, lest GE rescind the new policy and the industry revert to the "cutthroat competition" that characterized the 1960-early 1963 period. In any event, any element of uncertainty was quickly eliminated when Westinghouse published its own price book (essentially equivalent to GE's) and adopted its own price protection clause in 1964. (In the interim, Westinghouse quoted prices based on GE's published price book.) Subsequently, there was a pattern of identical, nondiscounted prices for at least the next several years. There was no evidence of any formal communication or agreement between GE and Westinghouse, either an agreement on price or an agreement to implement the price book or the price protection clause.

Had the Justice Department litigated the matter from scratch, it likely would have asserted that the specific actions taken "constituted" an unlawful agreement under section 1. In effect, the claim would have been that the independent yet parallel adoption of the new policy by GE and Westinghouse had brought about a meeting of the minds and facilitated the elimination of price competition. However, when the Department informed GE and Westinghouse that it was prepared to file a civil antitrust suit and indicated the relief it would seek, the parties offered to settle the matter, and provide all the relief that was desired, so long as it was treated as a modification of the outstanding 1962 consent decree rather than a consent in a new, freestanding, law- 
suit. For reasons spelled out in the Competitive Impact Statement (acknowledging the risks inherent in any litigation based on a somewhat novel theory), the Department accepted the offer, and the decree, containing significant restrictions on future behavior, was entered in 1977. However, while the court entered the modification of the consent decree as requested, this required merely that the court find the modification to be in the public interest, and there is no significant sense in which the court demonstrated its agreement with the Department's theory of what constitutes an agreement. ${ }^{64}$

2. PETROLEUM PRODUCTS Petroleum Products ${ }^{65}$ was a private treble damages action under section 1 in which the plaintiffs (several states) were appealing a district court's grant of summary judgment in favor of a number of the major oil companies operating in the western United States. The basic allegations were that the defendants engaged in various methods of disseminating information concerning their wholesale prices, including press releases (sometimes in advance of the effective date) and "posting" of the prices at various locations that were accessible to the other defendants. In part because the wholesale customers for each refiner (the distributors) were contractually bound to buy from that refiner (i.e., they could not "shop around" for better prices from other refiners) and in part based on other evidence, the appellate court concluded that there could be no other purpose for the dissemination of wholesale prices than to inform competitors of one another's price movements so as to make it easier for competitors to follow those movements. The court found that these actions had allowed the defendants to maintain supra-competitive wholesale and retail prices for gasoline sold at the wholesale level.

64 A case with some features in common with GE-Westinghouse was Jays Foods v. Nat'l Classification Comm'n, 646 F. Supp. 604 (E.D. Va. 1985), in which it was alleged that a trade association published a rate classification manual that facilitated the actual fixing of rates for the shipment of agricultural commodities. The court concluded that the manual did not in fact have the effect of allowing the competitors to fix or coordinate rates. It is unclear what the court would have decided if it had concluded that, while there was no agreement on the actual rates, the manual facilitated coordination of rates.

65 In re Coordinated Pretrial Proceedings in Petroleum Prods. Antitrust Litig., 906 F.2d 432, 444 (9th Cir. 1990). 
Under these circumstances, the court asserted, "[a] jury could conclude that the oil companies agreed, either implicitly or explicitly, to create market conditions that would facilitate tacit or express price coordination." 66 It is interesting (and perhaps unfortunate) that the court invoked the notion of agreement twice: the parties agreed (either implicitly or explicitly) to facilitate an agreement (explicit or tacit) on price. If in fact a jury concludes that there is a tacit agreement on price, it is unclear whether or why they must also conclude that there was an agreement (either tacit or explicit) to engage in the facilitating practices. It is also unclear how the jury is supposed to decide whether there was a tacit agreement on price unless the court is in effect instructing the jury that the use of facilitating practices to coordinate prices constitutes a tacit agreement and, if so, whether it is necessary that the jury also find an agreement to engage in the facilitating practices. ${ }^{67}$

3. AIRLINE TARIFF PUBLISHING (ATP) In another nonlitigated application of the facilitating practices approach, the Justice Department filed a Sherman Act complaint against the major airlines alleging that the airlines signaled one another about possible future prices with the intent and effect of suppressing price competition.68 All the major airlines are linked by computer, and all submit information about their own fares and are able to receive information about fares of rival airlines. This fare information also provides the core of the computerized reservation systems used by travel agents. The airlines allegedly used the computer link to communicate intentions about fares to be charged in the future. The Department's press release asserted: "The airlines engaged in a process that involved repeated exchanges through ATP [the computer network] of

$66 \quad$ Id. at 448 .

67 To complicate matters, a subsequent Ninth Circuit decision asserted that the court in Petroleum Products found evidence of a (formal) agreement, so that the discussion of facilitating practices as a possible Sherman Act violation was dictum. See In re Citric Acid Litigation, 191 F.3d 1090, 1096 (1999).

68 United States v. Airline Tariff Publ'g Co., 836 F. Supp. 9 (D.D.C. 1993); United States v. Airline Tariff Publ'g Co., 1994-2 Trade Cas. 70, 687 (D.D.C. 1994); see also Severin Borenstein, Rapid Price Communication and Coordination: The Airline Tariff Publishing Case (1994), in The ANTITRust Revolution (J. Kwoka \& L. White eds., 1999). 
price increase proposals and counterproposals, with the effect of raising fares to consumers." 69 A principal allegation was that an individual airline would indicate in the computer that a fare increase on a given route for a given travel period would be implemented, not immediately, but at some time in the near future, e.g., in seven days. For travelers purchasing tickets during the seven-day window, the proposed increase would be irrelevant, as the fares would still be identical, so the airlines initiating the fare increase would not expect to lose any sales to its competitors during this period. The seven-day window would allow the first airline to see if its competitors would match the price increase (effective the same day). If so, the new fares would go into effect on the same day for all the airlines. If not, the first airline could simply rescind the proposed increase before the end of the seven-day period without having suffered any lost sales (as it would have had it initiated the price increase effective immediately and its rivals had not matched).

The Justice Department's claim was that this process allowed airlines to exchange "assurances" about future fares in the same fashion as members of a cartel, sitting around a table in a smoke-filled room, saying, in effect, "I'll raise prices next week if you will." In more complex scenarios, airlines allegedly "negotiated" the precise amount of the increase if they had different ideas about the most profitable price. The Department claimed that this constituted an illegal agreement under section 1 . The matter was settled with a consent decree in which the airlines agreed to eliminate advance announcement of price increases. While the complaint alleged agreement, there was no plausible claim that, when an airline announced a fare increase, it did so with any assurance that rivals would follow, since many announced fare increases were rescinded or modified. Rather the essence of the claim had to be that the parallel use of advance price announcements facilitated the coordination of price changes by eliminating the risk of initiating a price increase. ${ }^{70}$

69 Press Release, U.S. Dep't of Justice, Justice Department Files Price Fixing Suit Against Eight Airlines and Fare Dissemination System (Dec. 21, 1992), http://www.usdoj.gov/atr/public/press_releases/1992/211323.htm.

70 An alternative interpretation, which avoids the need to allege a tacit agreement on price, would be that the parties agreed to use advance 
4. TODD v. EXXON Todd v. Exxon ${ }^{71}$ is one of a number involving the exchange of pricing information. ${ }^{72}$ Here, the information was about salaries paid to various categories of employees and it was exchanged among several oil and petrochemical companies that were the primary employers for these types of employees. Plaintiffs claimed that salaries were set at artificially low levels and that the exchange of salary information was a key explanatory factor. The opinion discusses two different ways that such information exchanges might be analyzed. The first involves a combination of the plus factors approach with the facilitating practices approach. The plaintiff alleges an agreement on price. In the absence of "smoking gun" evidence, the agreement would be inferred on the basis of conscious parallelism when such interdependent conduct is accompanied by plus factors. The plus factors would include

price announcements and that these facilitated coordination of price increases, but any agreement on the use of advance price announcements would have to have been a tacit agreement, since there was no allegation of any explicit agreement in this regard. This takes us back to the issue of what distinguishes a tacit agreement to use advance price announcements from merely conscious parallelism in the use of such announcements. Advance announcement of price changes was also an issue in Reserve Supply Corp. v. Owens-Corning Fiberglas Corp., 971 F.2d 37 (7th Cir. 1992). The court indicated that advance announcements might have the effect of facilitating the parallel pricing that characterized the industry, but rejected this aspect of plaintiff's claim because it concluded that the practice served an important legitimate purpose. And as a small element in a much larger set of allegations, plaintiffs in the Williamson Oil case claimed that the cigarette companies' use of "credit memos" effectively constituted advance announcement of price increases, which in turn facilitated parallel pricing. However, the court disagreed that the credit memos had this effect. Williamson Oil Co., Inc. v. Philip Morris, 346 F.3d 1287, 1294-96 (11th Cir. 2003).

71275 F.3d 191 (2d Cir. 2001).

72 The Blomkest case, discussed supra section II D, involved allegations of information exchanges about price ("price verifications") but the opinion was not framed in the language of facilitating practices. Blomkest Fertilizer, Inc. v. Potash Corp. of Sask., 203 F.3d 1028 (8th Cir. 2000). The case is better seen as a contest between the plaintiff, alleging a price-fixing agreement that can be established through circumstantial evidence (including plus factors), and the defendant, claiming that any parallelism in prices was the natural result of oligopolisitic interdependence. 
defendants' use of facilitating practices such as information exchanges. In this version, the plaintiff must allege an agreement on price but the court does not indicate that the plaintiff must also allege an agreement to exchange information. ${ }^{73}$ The second variant dispenses with the need to allege an agreement on price but requires an allegation that the parties agreed to exchange price information. This agreement can be evaluated under the rule of reason as to whether it had a significant anticompetitive effect. This version is the lineal descendant of the Container Corp. case, ${ }^{74}$ except that the confusion at the time of the decision as to whether such information exchanges could be held illegal per se has since been clarified in subsequent cases. ${ }^{75}$ So the second version, while it might be seen as implementing a facilitating practices framework, neither requires the language of facilitating practices nor involves any advance in the law relating to the exchange of information. ${ }^{76}$

5. DU PONT v. FTC ("ETHYL") The Ethyl case ${ }^{\text {ग7 }}$ differs from the other cases discussed in several important respects. First, it was brought not under the Sherman Act but by the Federal Trade Commission under the section 5 of the FTC Act ${ }^{78}$ alleging that the conduct complained of

73 However, it would not be a major leap to infer an agreement to exchange information since there is no plausible explanation why one company would provide information on its own salaries unless there was a quid pro quo that the others would provide similar information on their own salaries.

74 United States v. Container Corp., 393 U.S. 333 (1969).

75 The process of clarification is discussed in the Todd opinion, 275 F.3d at 198-99. Key cases include United States v. Citizens \& S. Nat'l Bank, 422 U.S. 86, 113 (1975), and United States v. U.S. Gypsum Co., 438 U.S. 422, 441 (1978).

76 In the actual case, the plaintiff did not allege any actual agreement among defendants to fix salaries so only the second approach was used by the court in rejecting defendants' motion to dismiss the complaint.

7 E.I. du Pont de Nemours \& Co. v. Federal Trade Comm'n, 729 F.2d 128 (2d Cir. 1984).

7815 U.S.C.A. $\$ 45$. It is generally accepted that any conduct that violates the Sherman Act a fortiori violates section 5. More controversial is whether section 5 prohibits conduct that would not violate the Sherman Act. 
constituted an "unfair method of competition."79 Second, while the basic conduct being attacked was analytically similar to the facilitating practices cases brought under the Sherman Act, the FTC specifically (and deliberately) did not allege any agreement among the respondents, either an agreement on prices or an agreement to adopt the facilitating practices. Rather the basic claim was that the parallel use of facilitating practices by several of the defendants, with the effect of reducing (price) competition among them, constituted an unfair method of competition under section 5. Given the limitations of the statute, only injunctive relief was sought. There could be no criminal penalties and there would have been no private right of action based on a finding that section 5 had been violated.

The case has been extensively discussed in the literature. ${ }^{80}$ The respondents were the four producers of lead antiknock additives for gasoline. The challenged practices were: (1) quoting prices on a uniform delivered price basis; (2) announcing price increases to customers and to the press well in advance of the effective date of the price increase; and (3) including in contracts with individual customers a clause requiring the seller to extend to that customer any discount offered to any other customer. Both the administrative law judge and the full Commission determined that the conduct violated section 5 , but those findings were overturned by the Second Circuit. While not completely rejecting the fundamental legal argument on which the

79 The FTC has brought other cases under section 5 based on defendants' use of price signaling as an illegal facilitating practice. See, e.g., YKK Inc., [1993-1997 Transfer Binder] Trade Reg. Rep. (CCH) II 23,355, at 23,030 (July 1, 1993) (consent order); AE Clevite, Inc., [1993-1997 Transfer Binder] Trade Reg. Rep. (CCH) II 23,354, at 23,029 (June 8, 1993) (consent order); Quality Trailer Prods. Corp., [1993-1997 Transfer Binder] Trade Reg. Rep. (CCH) II 23,246, at 22,932 (Nov. 5, 1992) (consent order).

80 I have written about it myself on several occasions from the perspective of the expert witness for the FTC. See, e.g., Hay, supra note 47, at 128; George A. Hay, Practices that Facilitate Cooperation: the Ethyl Case, in THE Antitrust Revolution (J. Kwoka \& L. White eds., 1999). For other (perhaps less biased) discussions, see, e.g., Lee Goldman, Oligopoly Policy and the Ethyl Corp. Case, 65 Or. L. Rev. 73 (1986); Donald S. Clark, Price-Fixing Without Collusion: An Antitrust Analysis of Facilitating Practices After Ethyl Corp., 1983 Wis. L. REv. 887 (1983). 
complaint was based (that parallel adoption of certain facilitating practices can violate section 5 if the consequence is a substantial reduction in competition), the court rejected the application of the theory to the facts in a way that suggests some of the obstacles that may confront a plaintiff seeking to use the facilitating practices language and theory in a Sherman Act case. Rather than debate the merits of the Second Circuit's analysis, it is sufficient simply to flag those potential problems.

First, not all competition had been eliminated. There was still some price competition (largely from the two smaller competitors that engaged in some discounting) and some nonprice competition (among all of the defendants). In a classic horizontal price fixing case, evidence of some continuing competition will not relieve defendants of liability if the court finds that they have agreed (explicitly or tacitly) on price. However, if all of the evidence is circumstantial, then the strength of the inference of an agreement will vary inversely with the extent of price competition, although there is no theoretical bright-line test for how much residual price competition would be fatal to plaintiff's case. ${ }^{81}$

Second, given that the industry was highly concentrated, and the product was fungible, even in the absence of the facilitating practices, the strong interdependence would have some dampening effect on price competition; i.e., it would not be expected that the industry would perform perfectly competitively. Of course in a traditional Sherman Act case where the agreement to fix price has been established, it is no defense to liability (although it may be relevant to the amount of damages in a private treble-damages action) to say that, even in the "but for" world, there would not have been vigorous competition anyway. But in a case where the plaintiff is asking the jury to infer a tacit agreement based on the parallel use of facilitating practices, an argument that the practices had no impact on the degree of competition because, even without the practices, there would have been no greater degree of competition, would be damaging to the plaintiff's case. The

81 It is not clear how the presence of nonprice competition would affect the inference of an agreement. One might argue that a certain degree of nonprice competition can be the natural effect of an agreement on price. Of course, if there is extensive nonprice competition it will ultimately undermine the stability of any agreement on price. 
practical question confronting the plaintiff will be to establish how much of a difference, as compared to the "but for" world, the facilitating practices made, and then the legal or policy question of how much of a difference is required for the plaintiff's case to have merit.

Third, whether or not the parties recognized the ongoing effect of the practices in suppressing price competition, the practices had not originally been implemented for that purpose, ${ }^{82}$ and there was a plausible argument that the practices continued to generate some efficiencies. For section 1 purposes, this raises the question of whether the plaintiff must show that the parties implemented or maintained the use of the facilitating practices with the purpose of suppressing price competition or at least with the knowledge that they had this effect and the further question of whether any efficiency rationale is fatal to the plaintiff's case and, if not, how to do whatever balancing is called for.

\section{CONCLUSION}

Whatever the underlying economic theory, a plaintiff seeking to succeed under section 1 of the Sherman Act must still allege an unlawful agreement. If the courts were wedded to the notion that an agreement must be explicit to be unlawful, then the concept of facilitating practices would have little practical value. ${ }^{83}$ Thus, even if the economist made a persuasive case that the parties did in fact coordinate their actions, and that their ability to do so was due in substantial measure to the use of certain practices that facilitated the coordination, and that the practices had little or no independent justification, the plaintiff would still confront the question: "Where is the agreement?"

But at least in principle, some courts have accepted the notion that there can be an illegal agreement even when no words are exchanged

82 The practices had originally been implemented by the Ethyl Corporation when it was the monopoly supplier of the product.

83 The theory might still be usefully applied to practices such as agreements to exchange information in order to explain how such an exchange can lead to supra-competitive prices. But in such cases, the agreement that the courts focus on is the agreement to exchange information and such agreements are evaluated under the rule of reason. This breaks no new legal ground. See supra notes 74-75 and accompanying text. 
and no formal commitments are made. That a tacit agreement can still be an unlawful agreement is not a novel proposition. What the facilitating practices approach contributes is a way to make the concept of tacit agreement operationally meaningful and to distinguish a tacit agreement from conscious parallelism or mere oligopolisitic interdependence. The suggestion is that when a group of firms has managed to coordinate their actions in such a way as to achieve supra-competitive prices (or some other anticompetitive result) and that coordination was facilitated by certain practices that the firms have engaged in which have no offsetting business justification, then the coordination can be described as constituting a tacit (and therefore unlawful) agreement. ${ }^{84}$

This is not to say that the facilitating practices approach is a plaintiff's panacea. The Ethyl case suggests that, even if the court accepts the general approach, there will still be substantial evidentiary burdens that the plaintiff must overcome. ${ }^{85}$ But some of these are really no different from those that the plaintiff faces any time it is asking the court to infer an agreement from circumstantial evidence.

The one feature that may be somewhat unique to the facilitating practices approach is the issue of whether there is a "business justification" for the practices and how powerful that defense ought to be. Does a plaintiff have to show that there is utterly no legitimate purpose served by the practice, or merely that the anticompetitive effects significantly outweigh any procompetitive justification? In a world of perfect evidence, the latter should be adequate, but the world is not

84 Since the "agreement" is the coordination of activity through inappropriate means (the facilitating practices), it should not really be necessary that the firms agreed to engage in the practices. That said, in many cases, since the facilitating practices are not "normal" business practices, it should be possible to argue that each firm would not have engaged in the practices without some understanding that rivals would do the same. But there will be exceptions, so it is important to maintain the principle that no agreement to engage in the practices is required.

85 E. I. du Pont de Nemours \& Co. v. Federal Trade Comm'n, 729 F.2d 128, 137 (2d Cir. 1984). And, of course, Ethyl was brought under section 5 of the FTC Act, with no criminal penalties and no private right of action. One should not be optimistic that a section 1 court will be less demanding. 
perfect and the Ethyl opinion suggests that the plaintiff has a major problem if defendant can show even a modest efficiency rationale. ${ }^{86}$ Despite these evidentiary problems, the facilitating practices approach has merit. Indeed, it may provide the best solution yet to the puzzling question: “What is a tacit agreement?" However, despite recognition by a few courts, the concept is still nascent and thus it remains to be seen whether facilitating practices analysis will be accepted as a legitimate approach under section 1 of the Sherman Act.

86 Ethyl, 729 F.2d at 139-40. A similar issue may arise where the plaintiff is asserting that the fact that defendants were often in contact with one another (e.g., at trade association meetings) should support an inference of agreement. Defendants will want some limiting instruction to the effect that trade association meetings are normal and legitimate and that merely the fact that the firms were together should not suggest that they necessarily did anything unlawful. 